Journal of Southeast Asian Human Rights, Vol.5 Issue. 1 June 2021 pp. 94 - 99

doi: 10.19184.jseahr.v5i1.24717

(C) University of Jember \& Indonesian Consortium for Human Rights Lecturers

\title{
Book Review: Author: Al Khanif; Title: Religious Minorities, Islam, and the Law: International Human Rights and Islamic Law in Indonesia; Publisher: Routledge, 2021
}

\author{
Abubakar Eby Hara \\ Department of International Relations, University of Jember \\ Email: eby-hara.fisip@unej.ac.id
}

\begin{abstract}
The book reviewed in this article examines religious minority rights in Indonesia, from both international and local human rights perspectives. Its main contribution lies in the effort to locate Indonesia's unique approach to managing minority rights in religion. This study leads the author to a rich discussion of how human rights activists advocate for the freedom of every citizen and how representatives of religious orthodoxy respond to it. In contrast to analysts who apply dichotomous views regarding the acceptance or rejection of international human rights principles, the author recognizes the complexity of the process of translating and spreading these values. The values secular values of human rights undergo a process of localization to modify them in line with local and cultural values, making them an integral part of society. In this view, the author refers to the Indonesian State as a 'quasi-theistic secular state,' meaning that Indonesia is a secular country but tries to guarantee freedom of religion and worship. Regarding minority rights, the State prioritizes harmony in society and supports the orthodox views of the majority. The minority view must be assimilated with the orthodox teachings of Islam to ensure protection from the State. The quasi-theistic secular state continues to experience contestation and has undergone a long construction process based on the narration of the peaceful entry of Islam and the relatively moderate character of Indonesian Islam. At a certain level, this concept of the State has developed into an identity and norm that serves as a reference for how to treat religious minorities. The author demonstrated that Indonesia is an example of a country that has successfully developed its own identity and religious norms that differs from the Western secular state system.
\end{abstract}

This article reviews Al Khanif's book entitled: "Religious Minorities, Islam and the Law, International Human Rights and Islamic Law in Indonesia." Based on this title, and background of the author, one can easily assume that this book will take a rigid, formal, legalistic approach to examine the law relating to religious minorities. Often, legal studies will present a case for what is legally 'right' and 'wrong' but do not explore 
the very complex process of implementation of particular legislation. This initial assumption is proven wrong when the book is read in its entirety. The author moves beyond the realm of conventional law in examining this controversial topic, focusing on the contestation of various perspectives from the international human rights and Islamic law, which are highly complex and dynamic. He also refers to the very complicated context of customs, culture, society, and politics in Indonesia. This makes this study very rich and enlightening.

Specifically, this book seeks to comprehensively discuss how the rights of minority groups in Islam are guaranteed in a non-liberal country like Indonesia. In a secular, liberal country where religion and state are separated, the guarantee of individual freedom is generally enshrined in the constitution and has become a norm that is taken for granted. In Indonesia, such guarantees do exist, but their interpretation and implementation do not tend to serve the interests of religious minorities. While the constitution does allow people to embrace religion and their related practices, the Blasphemy Law circumscribes the protections afforded by the constitution, limiting the freedom of religious minorities to interpret and apply their beliefs. In some cases, followers of these minority sects are not only considered heretics, but are also subject to exile and persecution.

In this book, the nuances of religious minority rights in Indonesia are discussed from a range of perspectives. The primary concern is how International Human Rights Law (IHRL) regulates the legal position of religious minorities, especially their religious freedom, as well as how Islamic law addresses the rights of religious minorities. International perspectives have received attention because they are supported by many human rights activists in Indonesia, rendering them important to the discourse on human rights in Indonesia. Some of their views on minority rights clash with the principles, concepts, norms, and customs of religious life in Indonesian. Crucially, the author centres the debate around the Pancasila State principle which adheres to secular norms but acknowledges the importance of religion in society.

Overall, the author is successful in meeting the goals set out above, providing information on the rich international human rights discourse as it relates to the rights of religious minorities. Likewise, we get a broad and deep account of the debate around minority rights in Islamic law.

Minority rights in Islam in Indonesia are considered alien or foreign by most Indonesian people who emphasize the importance of community and harmony. Islamic religious minority groups and organizations such as the Islamic Unity (Persatuan Islam, Persis), the Islamic Defender Front (Front Pembela Islam, FPI), the Islamic Community Forum (FPUI), Jamaah Islamiyah (JI), the Indonesian Party Liberation (Hizbut Tahrir Indonesia, HTI), and the Holy Warriors Council (Majelis Mujahidin Indonesia, MMI) have experienced hard rejection from Indonesian communities. Moderate Islamic organizations, such as NU and Muhammadiyah, who 
seek a more peaceful solution are more adherent to the orthodoxy of the dominant Islamic religion in Indonesia.

The author notes that the role of the government represented by the Ministry of Religious Affairs (MORA), Indonesian Ulama Council (MUI), and Bakorpakem is inclined to the majority view to maintain social harmony. This is often considered contrary to international human rights principles, and even contrary to the Indonesian constitution which enshrines freedom of religion for all Indonesian citizens. It is also interesting to see the author's view that the principle of a purely secular state is not capable of overcoming such complexities. He said the concept of a quasi-theistic secular state in Indonesia was needed because of the State's role as guardian of religious life due to the separation of state and religion. This concept is necessary because human rights, especially the rights of religious minorities in Islam in Indonesia, are dependent on legitimation from mainstream Islam as the majority religion. It appears that a purely secular human rights approach will fail to solve the problem of religious minorities in Indonesia, as it would require the majority of mainstream Muslims to subject their religion to a criteria that many would perceive as non-Islamic. Thus, the quasi-theistic secular approach provides space for Indonesians to choose and practice their religion or belief and, at the same time, allows the government to intervene in people's religious lives on occasion to protect public order.

In this context, the author emphasizes the need to continue to include religious discussions in the context of international human rights, so that the possibility of Islam adopting human rights is greater. The more Islamic perspectives are excluded from human rights discussions, especially discussions relating to religious minorities, the less likely it is that religious adherents (Muslims) will accept the universality of human rights (p. 94). This book is an attempt at building quasi-theistic secularism in Indonesia that does not ignore religious values as a source of law and morality. The author maintains that the right solution to address the human rights problem in an Islamic society is to combine religious and secular human rights approaches rather than adopting the Western concept of secularism (p. 94).

The author completes his study with a case to revoke the Blasphemy Law through the Constitutional Court (MK), appealing to the limitations it places on individual freedom. The case put forward is substantive given its relation to the dynamics between international human rights principles and local values. In the author's analysis, the MK did not completely reject the judicial review but highlighted the need to look at social and community aspects in its decision. The MK referred to security and religious harmony based on the mainstream view of the Muslim majority as well as social and customary considerations to justify the continuation of the law.

Besides some of the positive contributions of this book, which I will describe, there some limitation. To understand this book well, the reader must read between the lines to understand the subtext of each chapter. While the author's description very rich, it is sometimes too complex and difficult to follow. This is, of course, quite 
difficult non specialist readers who would likely benefit from an overview covering the core content of each chapter. This could easily be accomplished if structured with a brief introduction at the beginning, and a conclusion at the end, of each chapter.

This issue, however, does not detract from the book's important contributions. First, the author sees that the concept of international human rights cannot be directly applied to non-Western contexts, highlighting the need to pay attention to the specific social and political landscape within which it will be applied. This often requires a deep modification process. In this case, the liberal idea in international human rights that emphasizes individual rights and freedoms is not necessarily rejected but is subject to process of serious debate. The terms 'liberalism' and 'secularism,' as promoted by international human rights activists, are seemingly incompatible with the practices of some religious groups. The debate, and then acceptance, of these values will be more successful if the human rights vocabulary is modified to align with the terms and values that exist in Islamic traditions and practices in Indonesia.

The interpretation of individual rights in Islam is subject to a long process of dialogue and negotiation. This process shows that it is not a dichotomy of accepting or rejecting a particular view. It is common belief that if a country rejects international human rights, then it will be considered a pariah state and labelled as human rights violators. However, in this book, the author shows that there is a process of modifying and localizing norms ${ }^{1}$ and even terms that are considered foreign to non-Western norms and belief systems.

Secondly, this book shows that, apart from the modification and localization of international human rights values, or the interpretation of certain Islamic laws, Indonesia has always followed the structure of a secular state that acknowledges the importance of the role of religion in society. In Acharya's terms, this can be considered a 'subsidiary norm' where the state develops its identity which differs from the Western norm. ${ }^{2}$ This concept of the state continues to be institutionalized and provides a normative framework for religious life. Of course, the idea of a state based on Pancasila is not static. The process of forming the Pancasila state, which the author of this book calls 'secular theistic,' has a long history and acts as a reference point for the identity of the Indonesian nation. This journey of national identity can also be traced through the history of the relatively peaceful entry of Islam into Indonesia.

This situation can be said to be the uniqueness of Indonesian identity in interpreting freedom. In the Pancasila state, the secular approach is considered inappropriate and unable to address religious struggles in Indonesia. The author states:

1 Amitav Acharya, "How Ideas Spread: Whose Norms Matter? Norm Localization and Institutional Change in Asian Regionalism” (2004) 58:2 International Organization 239-275.

2 Amitav Acharya, "Norm Subsidiarity and Regional Orders: Sovereignty, Regionalism, and RuleMaking in the Third World” (2011) 55:1 International Studies Quarterly 95-123. 
'This means that Indonesia does not embrace French secularist "laïcité" but is a religious-secular state, whose public realm is dominated both by religious discourse and human rights discourse. Thus, secularism in Indonesia cannot be defined as "the total disestablishment of religion" from the public sphere as experienced by Christianity in Europe and North America' (p. 93).

The author also quotes An-Na'im when referring to the role of secularism to regulate the relationship between religion and the state. Various public policies have been implemented so that the freedom of religion and belief as a whole can be maintained in this pluralistic country (p. 93).

Third, this book offers an example of a relatively peaceful religious life for a country with a very plural religion and belief system. This is different from countries in the Middle East which are relatively homogeneous as a nation but continue to experience serious armed conflicts. In these countries, the role of the state is indeed important in overcoming differences. But a state that is too authoritarian and uses its power for political purposes will spark many protests and even armed resistance. In the conceptualization of Indonesia as a quasi-theistic secular state, the state is required to act as the neutral guardian of religious life.

The quasi-theistic secular approach in Indonesia provides space for Indonesians to choose and practice their religion or belief while empowering the government to intervene in people's religious lives on occasion to protect public order. Although there is a tendency to maintain the dominant religious values represented by MORA, MUI, and other major Islamic organizations, international human rights discourse remains open and activists have maintained space to present their views, including attempts to revoke the Blasphemy Law. Such a process creates an incremental change in laws to prevent turmoil, protests, and potentially violent opposition. The involvement of the Indonesian state has so far succeeded in protecting Indonesia from serious conflicts, such as those experienced in the Middle East.

Fourth, this book also bridges the dichotomy of cosmopolitan and communitarian ethics in human rights studies. The two approaches are fused when the author discusses the rights of Islamic minorities in Indonesia. For example, the principle of universal human rights has not been rejected but continues to be carried by human rights activists. To a certain extent, the principle of universality has established itself in relation to various views of religious freedom in Indonesia. In this context, restrictions on minority rights in Indonesia are no longer understood purely as part of the communitarian paradigm due to the acknowledgement that certain restrictions are necessary to maintain and guarantee the peaceful existence of wider religious freedom in Indonesia. In terms of liberalism, this is a rationality that must be accepted to maintain freedom itself. On the other hand, local values that are prioritized by communitarians are not static due to the creative tension experienced when faced with 
the demands of international human rights principles and various global interpretations of Islam.

In short, this book is an important reference for scholars, students, and human rights practitioners in various countries.

\section{BIBLIOGRAPHY}

Acharya, Amitav, "How Ideas Spread: Whose Norms Matter? Norm Localization and Institutional Change in Asian Regionalism” (2004) 58:2 International Organization 239-275.

—-, "Norm Subsidiarity and Regional Orders: Sovereignty, Regionalism, and RuleMaking in the Third World” (2011) 55:1 International Studies Quarterly 95123.

Dr. Abubakar Eby Hara is a lecturer at the Department of International Relations, University of Jember. His research interests are in regional human rights issues and global issues such as democracy and human security. Currently, his main research is related to Indonesian public diplomacy in Myanmar, the role of AICHR, and Islamic populism in Indonesia. 